\title{
If Indonesia is Too Hard to Understand, Let's Start with Bali
}

Graeme MacRae

Massey University

\begin{abstract}
Stereotypical representations, especially those by the media, are for most outside observers, the means and an obstacle to understanding Indonesia. One way around such stereotypes is to look at the way Indonesians themselves understand Indonesia. This essay reports and reflects on Balinese understandings of Indonesia in the wake of the political, economic and terrorist upheavals of the early years of the twenty-first century. It concludes with an epilogue and update, arguing that the real issues for understanding Indonesia are now environmental.
\end{abstract}

\section{Understanding Indonesia}

'Understanding' Indonesia is no easy matter for non-Indonesians. Looking from the outside, usually through media representations, we tend to see something large and monolithic, which we habitually apprehend through such simplifications as 'the world's most populous Muslim nation' or 'an authoritarian state in transition to democracy', or a place where nice Australian kids are imprisoned for things they say they didn't do - things we might not think are all that bad anyway. Such simplifications and stereotypes are inevitable, but they obscure a lot more than they reveal. Our job as scholars with claims to some kind of deeper understanding of Indonesia is to transcend such stereotypes and work toward deeper, more nuanced and more productive understandings.

What these stereotypes most obscure are the vast and multiple diversities in Indonesia. An example is the religious diversity not only between Islam and other religions but between the many different local and doctrinal approaches to Islam. The stereotypes also obscure the historical 
process by which the nation-state called Indonesia was constructed and is maintained. When we look at this process, the labour of creating unity from diversity becomes visible and any illusions of essential unity slip away quickly. The stereotypes also obscure the consideration that understanding any place, including Indonesia, depends from where we look: Australia or America, East Malaysia or East Timor, ASEAN or the IMF, Jakarta or Jayapura.

For Indonesians themselves, the problems of understanding their own country are no doubt different but I think there is something to be learnt about Indonesia's relations with other countries by studying the ways outsiders see Indonesia. At best, some of these points of view of outsiders might even tell Indonesians something about their own country that is not so apparent to them. A first principle of anthropology is that one benefit of studying another culture is the new insights into our own culture that we derive in the process. This essay follows this principle but extends the principle a little further.

It is based on an outsider's point of view, but one in which I try to understand something about Indonesia through the way one group of Indonesians view their nation and their relationship with it. A range of understandings of Indonesia from say, Jakarta, Aceh, West Papua and Maluku, that is, from the extremities of the archipelago, would begin to provide a map of the range of these relationships and points of view. In my own case, whatever understanding I have of Indonesia comes primarily through my experience of living in Bali, among Balinese and listening and talking to them about their lives. In the process, I have learnt that they see their own country to some extent as all Indonesians do, but also from a very distinctively Balinese point of view. ${ }^{1}$

1 This paper is a revised version of one first presented at a symposium in New Zealand oriented to a general New Zealand audience rather than a specialist one on Indonesia, let alone to Indonesians themselves. In this version, the lens is rotated a further turn to speak to Indonesian social scientists. It is based largely on research conducted jointly with Nyoman Darma Putra and published separately (MacRae and Darma Putra, 2007; 2008; 2009) but also on regular research in Bali dating back to 1993. This was facilitated initially by the Indonesian Institute of Sciences (LIPI) and has been funded partly by Auckland and Massey Universities. 
Indonesia? What part of Bali is that? (attributed to an Australian tourist)

Bali is in some ways very Indonesian, close to the geographical centre of the country, with a culture blending elements of the historically Indic culture of Java to the west and the more Austronesian cultures of the islands of Nusa Tenggara to the east and, as well, it has a history linked to many key moments in Indonesian history. But it is also a very atypical part of Indonesia: more affluent than most parts of the country; possessed of both an economy more closely integrated through tourism within the global economy than to the wider Indonesian economy, and a contemporary culture likewise closely integrated with tourism; a contemporary culture likewise closely integrated with tourism; an island of Hinduism surrounded by a sea of Islam; and most Balinese people in recent decades have remained fairly peripheral to national political processes.

During the enforced tranquillity of the New Order, when it seemed that tourism and economic growth would never end, the Balinese enjoyed a complacent self-confidence about their prosperity and the religious and cultural superiority on which they believed it was based. Issues of who they were and their relationship with Indonesia as a whole were not especially important, nor were they safe subjects to talk about. During the 1990s though, as the tourism economy accelerated and various consequences, such as environmental problems and outside control of development, became increasingly apparent, many Balinese became concerned about what was happening to their island (Suasta and Connor, 1999; Warren, 1998; Ramseyer and Panji Tisna, 2001). After the downfall of Soeharto in 1998, a series of upheavals shook the tourism economy and the selfconfidence that went with it. In particular, after the bombing in Kuta in October 2002, Balinese society underwent a crisis of confidence about its economic future, cultural identity and relationship with Indonesia as a whole. Although things have recovered since and tourist numbers are now at their highest ever, the crisis of the early 2000s and the ways it was dealt with provide an insight into the way in which Balinese understand Indonesia, or at least their place in it. 


\section{Ajeg Bali}

On 27 May 2002, at the opening of a new locally-owned television channel, the Governor of Bali proclaimed that 'the noble mission and vision of Bali TV is the promotion and mengajegkan of Balinese tradition and culture along with tourism' (Darma Putra, 2004b). ${ }^{2}$ The root ajeg means something like 'standing strong, firm upright,' and one might render its verb form, mengajegkan, as roughly equivalent to the English expression to 'stand it back on its feet'. The origins of the concept are hazy, but it struck a chord; it was picked up and developed by a local media conglomerate comprising main local newspaper (the Bali Post), Bali TV, and a number of other magazines and radio stations.

As the initial shock of the bombings in Kuta wore off and the even more unsettling realisation set in that Bali might never be quite the same again, the Bali Post Media Group (BPMG), in August 2003, sponsored a public seminar, titled Menuju Strategi Ajeg Bali [Towards a strategy for Ajeg Bali], to which a range of intellectual, religious and business leaders were invited to present and discuss their views of the state of Bali and how best to approach the future. These discussions were published in the 55th anniversary edition of the Bali Post and subsequently as a book (in 2004) titled Ajeg Bali: sebuah cita-cita [Ajeg Bali: an aspiration]. A number of local intellectuals also wrote longer articles that were published in another book, Bali menuju jagaditha: aneka perspektif (Darma Putra, 2004).

The introductory chapter of Ajeg Bali: sebuah cita-cita (which was the editorial of the special issue of the Bali Post), written by the owner and head of BPMG, Satria Naradha, summarised a particular view of Bali, as '...identical with beauty, security, and harmony' and provided an analysis of the current problems: ${ }^{3}$

2 All translations are my own; this one from '...misi dan visi Bali TV yang sangat mulia yaitu mengembangkan dan mengajegkan adat dan budaya Bali ditambah dengan pariwisata Bali...'

3 For a discussion of the pervasiveness and genealogy of this self-image in contemporary Bali, see MacRae (2004). 
The people of Bali have begun to forget their sense of self. This sense of self that is based on religion and culture has begun to be pushed aside. The soil of Bali, which is a part of tradition, has begun to change hands. The culture whose breath is Hindu and which pioneered the bringing of Bali into the arena of international tourism, has begun to be replaced with outside culture. $^{4}$

and laid out the agenda of Ajeg Bali:

To protect the identity, space and process of Balinese culture. This remedy will flow towards raising the capacity of Balinese people so that they do not fall subject to the hegemony of global culture. ${ }^{5}$

Thus far Naradha is doing little more than reiterating a refrain about the dangers of Western cultural influence, which has been sung by foreign Baliphiles since the 1920s but has now also become deeply internalised in contemporary Balinese culture (MacRae, 1992; Vickers, 1989). But he proceeds to elaborate this danger in terms of two 'burdens' (beban) that Bali is carrying: 'of infrastructure, which is using up the land', and of 'the invasion of people competing for "a slice of the pie" " ${ }^{6}$

Ajeg Bali contains, as well as discursive articles, a number of programmatic summaries of perceptions of the problems and the strategies for dealing with them. One of these, titled Konsep Ajeg Bali: dimaknai dalam 3 tataran [The concept of Ajeg Bali: explained in three forms], lists the following 'threats' (ancaman):

4 Bali yang identik dengan keindahan, kenyamanan, dan keharmonisan sudah mulai terusik. Terusik, karena manusia Bali sudah kurang eling pada jati diri. Jati diri manusia Bali yang bedasarkan agama, adat dan budaya mulai dismapingkan. Tanah Bali yang merupakan bagian dari adat makin banyak berpinday tangah (sic). Budaya bernafaskan Hindu yang menjadi pioneer untuk mengangkat pamor Bali dikancah pariwisata internasional mulai digantikan budaya luar. (Bali Post, 2004:ii).

5 Untuk menjaga identitas, ruang serta proses budaya Bali. Upaya ini akan bermuara pada peningkatan kekuatan manusia-manusia Bali agar tiday jatuh di bawah penaklukkan hegemoni budaya global. (Bali Post, 2004: ii)

6 The Indonesian phrase, 'ingin merebut kue di Bali', is a colloquial expression, which means literally 'who want to get the sweet or cake of Bali' but corresponds in spirit to the English expression 'to get a slice of the pie'. 
- the implementation of regional autonomy

- social ills such as crime, prostitution and gambling

- the 'hedonistic' mental attitude of the Balinese themselves

- the gap between the letter of the law and its implementation

- commercialisation and commodification of culture

- non-selective immigration

- the power of big capital(ism)

The sources of these threats are not made explicit but, apart from the 'hedonistic' attitude of Balinese, the other threats appear to originate from outside Bali, in either the (national) government, or wherever it might be that immigrants, capitalism or 'social ills' come from. In popular Balinese thinking, these tend to be, respectively, 'Java' in general, 'Jakarta' in particular and a generic decadent 'Western' or 'global' culture and economy. ${ }^{7}$

Immediately following the list of threats there are 'practical recommendations' for dealing with these problems, recommendations that emphasise the strengthening of traditional institutions, the legislative protection of Balinese religious and cultural 'space', and 'selective migration' (Bali Post, 2004: 47). Similar themes and emphases are repeated throughout the book. Ajeg Bali thus seems to combine two basic agendas; a strengthening of Balinese culture from the inside and self-protection against outside influences of various kinds.

This discourse spoke to deeply held concerns at all levels of Balinese society. Ajeg Bali become a household word overnight and was used in all sorts of contexts. It was promoted systematically through television programs, newspaper articles and billboards; all repeating similar sets of vague but compelling messages about strengthening Balinese traditions and values. What Ajeg Bali meant in practice to ordinary Balinese

7 This generalisation is based on countless conversations with Balinese for over a decade as well as frequent letters to the editor of the Bali Post. 
is less clear. People to whom I spoke, and letters to the editor of the Bali Post (for example, Seriana, 2005; Yastaki, 2005; Wirawan, 2005) interpreted it in a wide variety of ways to suit their own perceptions of Bali's problems. Many spoke in general terms of safety and security (keamanan), some of 'protection' (membentengi, menjaga), others more explicitly of controlling immigration, and yet others of returning to traditional cultural and religious practices.

The 'invasion' referred to is not of the nation-state of Indonesia, but of the island-province of Bali. It comes not only from foreign or Western culture but also from within Indonesia, and it comes in two forms. The first is big capital, mostly from Jakarta, which controls an increasing share of the Balinese economy. The second invasion is the thousands of immigrants, mostly from East Java, who have taken over much of the bottom end of the economy, performing the hard, dirty, dangerous and poorly paid work that Balinese, especially in the affluent tourist areas, have been increasingly reluctant to do. Many Balinese have a growing sense that they are losing control of their own economy simultaneously from the top down and the bottom up.

But this discourse also reinforces and reflects long-standing concerns that Bali is a small island of Hindu culture in a vast sea of Islam, and that this sea is not necessarily well-disposed toward them (Picard, 2005). These concerns surfaced with increasing regularity, especially in the climate of economic stress and cultural uncertainty, after the bombings of 2002. The bombings were seen as the most extreme and threatening manifestation and indeed incontrovertible proof of this threat. ${ }^{8}$

The common ground in the Ajeg Bali discourse involved reclaiming control over resources, economic activity and physical and social space, which are widely seen as having been taken over by immigrants to Bali, mostly Muslims from Java. It also meant reviving a culture that is threatened by the degrading influences of 'foreign' (that is,

8 Readers should be reminded at this point that this discourse is not the only one purporting to represent social reality in Bali, nor is it necessarily an accurate picture of that reality. It is important to remember also that there are Muslim communities in Bali, which have lived in harmony with their Hindu neighbours for generations (see Barth, 1993). 
Western) culture. This is the (sometimes obscured) core of the Ajeg Bali discourse, but its genius lies in its vagueness, which leaves it open to many interpretations and able to incorporate new ideas and initiatives. ${ }^{9}$

Although Ajeg Bali is presented as a practical project for identifying and fixing some current problems, it is also a way Balinese have devised for talking between themselves about themselves and this necessarily means talking about their relations with places and people outside Bali. They seem to be saying several things at once, not all entirely consistent one with the other.

1 Hindu Balinese are the only true people of Bali.

2 The Balinese feel that they are losing control of Bali.

3 This loss of control manifests in various ways; cultural, religious, economic and political, but all are linked parts of a common underlying problem.

4 This underlying problem has two faces; influences and threats impinging on Bali from outside; and internal weaknesses in Balinese character, culture and economy.

5 The practical project of Ajeg Bali addresses these problems from both ends by simultaneously 'strengthening' Balinese culture from within and 'protecting' it against threats from outside. ${ }^{10}$

I want to concentrate now on what Balinese see as the main external influences and threats, because they tell us something about how one community of Indonesians understands its place in Indonesia and the world.

9 For a similar, but more comprehensive discussion of Ajeg Bali discourse, see Allen and Palermo (2005) and on Balinese fears about 'outsiders', see Schulte Nordholt (2007)...

10 For a similar analysis of the concept of 'Balinese culture' in the period immediately before the Ajeg Bali movement, see Santikarma (2001: 31). 


\section{Outside Ownership}

...many outsiders are only in Bali for the profits, their contribution to Bali is very minimal.

AA Puspayoga, Mayor of Denpasar ${ }^{11}$

During the 1980s, tourism in Bali grew from small beginnings into a major earner of foreign exchange not only for Bali but for Indonesia as a whole. This growth attracted investors from all over Indonesia and, during the 1990s, a series of increasingly large and expensive hotel, resort and golf course projects were built in Bali. Many were built by big investors from Jakarta, often in partnership with major international hotel chains. These projects required not only big capital but large amounts of land and various government permits (Warren, 1998).

Some Balinese were prepared to sell their land at the relatively high prices that the projects offered, others were not. The latter were offered inducements and encouragement, gentle at first, then not so gentle. If all else failed, the investors called on the government for help. These investors were often close associates of the Soeharto family, and were thus able to exert influence from the top down. They were also in a financial position to make the lives of Balinese government officials much easier. They were also able to make the lives of ordinary people less easy — some of those not prepared to sell their land had it compulsorily appropriated in the name of 'development'. These same political and economic forces were used to expedite the grant of permits that in many cases should never have been granted at all. The hotels and resorts were built and many smaller, Balinese-owned hotels have increasingly struggled to be commercially viable ever since.

In the main tourism centres, especially Kuta, not only big international hotel, restaurant and retail chains, such as such as McDonald's and Hard Rock Café, but also Jakarta-based national enterprises have taken

11 In the Bali Post of 18 May 2005. 
over the main streets, pushing smaller, locally-owned businesses into less desirable locations. Those of the original Kuta community who still remain live mostly on the proceeds of the sale or rent of their land. By the turn of the twenty-first century, it was estimated that 85 per cent of the tourism economy was in non-Balinese hands (Bali Post, 9 February 2005). As well as this shift of ownership of the tourism economy, the non-tourist sectors of the economy, especially farming, have been increasingly marginalised (MacRae, 2005).

In early 2005, Satria Naradha announced, with considerable fanfare, the formation of a new institution called Koperasi Krama Bali (KKB). Koperasi is a familiar term, referring to the mostly government-run cooperatives that have been a part of the Indonesian economic landscape for decades. They are most prominent in rural areas where they provide supplies to farmers, often on credit, but also small loans for various purposes. They have long been bedevilled by mismanagement and corruption and have suffered a considerable loss of public confidence. In recent years, with the liberalisation of the economy, they have waned in importance. At one level KKB seemed like just another koperasi but owned by the Balinese people (krama Bali) instead of the government. But the name also had a grander ring, along the lines of 'The Balinese People Inc.' - an umbrella for the collective advance of the Balinese economy along distinctly Balinese lines.

On 16 May 2005, the Governor of Bali, DM Beratha, signed as the first member and expressed his hope that KKB would promote the survival of the 'people's economy' (ekonomi masyarakat) by empowering small businesses and providing capital for farmers (Bali Post, 17 May 2005). Satria Naradha, as chairperson, as well as founder and primary sponsor of KKB, explained that it had been established to 'gather the strength of the Balinese people's economy' and would provide capital and advice to the (economically) weak. He also expressed the hope that the strong would help those less fortunate.

A day later, when a pair of candidates for the mayoralty of Denpasar joined, one of them, IBRD Mantra, said that the 'people's economy' economy' of Indonesia had begun to be 'pushed aside and taken over by 
the capitalist class' and that he saw KKB as a 'form of people's economy with the capacity to combat the growing strength of the capitalist class in Bali. The capitalist economy is not at all appropriate in Bali because it is only controlled by a minority of people, unlike the people's economy which has prevailed until recently'. His partner, AA Puspayogya, said $\mathrm{KKB}$ 'originated from the Balinese people, for the Balinese people' and described it as a 'bulwark' or 'fortress' (benteng) around the Balinese ekonomi. He added that many outsiders only came to Bali looking for profit and contributed little to Bali and that many Balinese assets had fallen into hands outside Bali (Bali Post, 18 May 2005). ${ }^{12}$

What this discourse shows is, with some justification, the remnants of a traditional small-scale Balinese economy in need of protection from big fish from Jakarta. What it ignores and obscures is the current extent of the integration of Bali with the global economy through tourism, exports and foreign businesses. This reality is, however, clearly acknowledged in much of the discussion that followed the 2002 bombings. This contradiction suggests that although Balinese in some respects understand themselves as Indonesian, in economic terms they do not - instead they identify themselves in terms at once inescapably global and assertively local.

\section{Immigration}

Ada gula, ada semut. [Where there is honey, there are ants]

Indonesian proverb

It is not only big capital that has been attracted to Bali by the tourism bonanza. Since the 1980s, an increasing flow of people from other parts of Indonesia, especially the relatively poor neighbouring provinces of East Java and Lombok, has come to Bali in search of work and a better

12 'Fortress' metaphors were common in Ajeg Bali discourse. For a broader discussion of this 'fortress mentality' see Schulte Nordholt (2007). 
life. By the mid-1990s, most of the hard, heavy, dirty, dangerous work in South Bali, especially building and road construction, was being done by immigrant men, many of them young and single. They also dominated the informal economy of street stalls, door-to-door sales of household goods, as well as scavenging for recyclable materials from rubbish. Javanese contract teams have also taken over much of the rice harvesting in the western half of Bali.

Such migrants are attractive for employers because they have a justified reputation for working longer and harder for lower wages. They also do not require the irregular but frequent time off work that Balinese employees expect for attendance at ceremonies. Balinese readily concur with this judgement and see little virtue in working as the Javanese do but are concerned about the immigration for other reasons. Although many migrants, especially in the tourism heartland of Kuta, left Bali after the bombing because of loss of employment and subsequent 'sweepings' by Balinese vigilante militias, many remained and more have arrived since.

Under national law, all citizens of the Republic of Indonesia are free to travel and settle wherever they choose provided they have employment, notify the local authorities and are registered as temporary residents (penduduk sementara). But their very presence presents a problem for the Balinese communities in which they live, because membership of such communities presupposes religious as well as social, economic and political participation. To be a community member also presupposes a state of marriage. Non-Balinese, and single people, cannot therefore become full members of local communities. So they live in a kind of social and especially religious limbo on the margins of Balinese communities. Such status is, however, less of a problem in urbanised areas, where communities are already mixed and much temporary rental accommodation is available, but in such urban communities it produces the opposite problem, that of immigrant neighbourhoods (kampung pendatang) in which Balinese feel like strangers.

Some immigrants flout the laws and arrive unregistered and invisible but also ripe for exploitation by unscrupulous employers. Even those 
who arrive legally are vulnerable to subsequent dismissal from their jobs at the whim of employers and the (not infrequent) financial difficulties of development projects. If this happens, they are stranded far from home without the safety net of family and community support; prostitution and petty crime become options of last resort for some. Thefts, rapes and other violent crimes are reported in lurid detail in the Balinese media, and non-Balinese names appear frequently among these reports. ${ }^{13}$ There is a widespread belief among Balinese that most, if not all, such crimes are committed by outsiders (pendatang), and more specifically by Javanese (orang Jawa). Local informal responses to crimes against property and person in Bali is immediate, collective, violent and often deadly. ${ }^{14}$ When crimes are committed, it is usually assumed the perpetrators are Javanese, and innocent Javanese have been known to find themselves in the wrong place at the wrong time. ${ }^{15}$

\section{Hinduism and Islam}

In June 2005, a document, titled Akhirnya Bali dalam genggaman [At last Bali is in our grip], was widely circulated in Bali. ${ }^{16}$ It supposedly appeared mysteriously in local community halls (balai banjar) all over the island and was framed as a speech to the people of Bali from the head of the main mosque in Kuta at a date five years in the future. It outlines a scenario in which (immigrant) Muslims constitute half the population of Bali, are already a majority in the capital Denpasar and have at least two large mosques in each other city as well as controlling the tourism economy. The real authorship, origin and intent of this document are subjects of speculation, but it articulates with chilling clarity a fear that has been widely held in Bali for a very long time. ${ }^{17}$

The Indonesian state is essentially secular, but among the fundamentals

13 I have no way of knowing how consistently or selectively these crimes are reported.

14 The crime page in the Bali Post contains frequent reports of alleged thieves being caught in the act, pursued by a mob of outraged locals and beaten or burnt to death.

15 For an account of a vigilante inspection, see Santikarma (2001).

16 I am grateful to M Blongoh of Banjar Taman, Ubud, for a copy of this document and his views of its significance.

17 On Balinese fears of being overrun by Islam, see Schulte Nordholt (2007). 
it requires of its citizens is 'belief in (the one) God'. It also specifies five religions through which this belief may be legitimately channelled, including Islam and Hinduism. But within this seemingly liberal and egalitarian framework, the reality is that some religions are more equal than others. The vast majority (around 86 per cent) of Indonesians are (at least nominally) Muslim, and Islamic concerns have, from the beginnings of the republic, been strongly represented in the political process; indeed, the whole official structure of religion in Indonesia is in important respects modelled on Islam. Although the vast majority of Indonesian Muslims subscribe to moderate interpretations of Islam, often deeply mixed with older Hindu or animist beliefs and practices, a minority would like to see Islam expand and even for Indonesia to become an Islamic state. Followers of religions other than Islam have at times been subjected to various forms of systematic disadvantage and marginalisation. ${ }^{18}$

Bali is one of the main exceptions to this pattern. Over 90 per cent of Balinese people are Hindu and they see their culture and local customs as inseparable from Hinduism. When most of Java was converted to Islam in the fifteenth and sixteenth centuries, the Balinese resisted fiercely and were never invaded nor converted. Small Muslim communities have, however, existed in Bali for centuries, coexisting harmoniously with their Hindu neighbours (Barth, 1993; Vickers, 1987).

Over the past couple of decades, however, as immigrants have flowed into Bali, they have brought their religions, which for most is Islam. Consequently there are now tens of thousands of Muslims in Bali. In some areas, especially the Kuta tourism zone and Denpasar, Muslims constitute significant minorities, sufficiently permanent to have built mosques. ${ }^{19}$ Concerns have thus surfaced, not only about the supposedly

18 For an example, see Hefner (1985). For general discussion of the politics of religion in relation to Hinduism in particular, see the edited volume Hinduism in Modern Indonesia (Ramstedt, 2004).

19 In Kuta in 1998, 13 per cent of the population were Muslim and barely three-quarters of the population Hindu (Pitana et al., 2002: 37). A more recent figure for the city of Denpasar has the Hindu population down to 67 per cent, a decline of 0.3 per cent per annum while over the same period the Islamic population grew at 0.26 per cent per annum (Rini, 2004a:27). For the whole of Bali the Hindu proportion declined from 93.3 per cent in 1980 to 87.4 per 
immoral and 'criminal' tendencies of Javanese immigrants, but about hidden religious agendas and their growing capacity to undermine Hinduism and impose Islam in Bali.

These views are an open secret in Bali and common knowledge to every researcher who has worked there and, indeed, obvious to many tourists. My primary evidence lies in the unsolicited testimony of dozens, if not hundreds, of Balinese during my research in Bali since 1993. These views come from various parts of the island and from all sectors of its society. They surface most visibly in situations of stress or threat, such as the thefts during the 1990s of sacred objects from temples (Santikarma, 2001) or the statement by a national parliament minister that Megawati Soekarnoputri was not a suitable candidate for the presidency because she worshipped Hindu gods (Couteau, 2002). The laudable absence of violence in the aftermath of the bombings in 2002 was attributable less to Balinese doubts about the source and purpose of the attacks than to their respect for social order, non-violence and the rule of law. The document referred to above is merely the latest manifestation of a barely concealed discourse of long standing.

These concerns are not, however, well-documented in either local or academic literature for obvious reasons. ${ }^{20}$ But they are visible in coded form between the lines of the Ajeg Bali discourse. For example, an article, ostensibly on religion (Rini, 2004a), in the Ajeg Bali book concludes with a 'Strategy towards Ajeg Bali' in the form of bullet points, of which one is 'to pay attention to the demographic factor (as a very significant factor influencing cultural development)'.

Balinese understand Indonesia as a country dominated by Muslims and themselves as a vulnerable non-Muslim minority, as do other nonMuslim minorities throughout Indonesia. Although they know they are citizens of Indonesia protected by its constitution, they believe that at

cent in 2000 (Rini, 2004b: 33).

20 There are still laws in Indonesia, albeit less rigorously enforced than during the Soeharto era, restricting discussion of SARA, an acronym (for suku, agama, ras, antar-golongan) for differences of ethnicity, religion and class, which might be mobilised to cause division and conflict. Since the end of the New Order, there have been some scholarly references to Balinese views of Islam, for example, Santikarma (2001), as well as in the local press. 
least some of the Muslim majority have hostile intentions toward them, and they are not confident of either the commitment or the ability of the government, national or even local, to protect their religion and culture. In this sense, Balinese understandings of Indonesia overlap on one hand with those of other minority populations in Indonesia (see, for example, Chauvel, 2009) but also, perhaps ironically, with certain aspects of Western, especially American and Australian, understandings. ${ }^{21}$

\section{The State}

During the 1990s, until the last days of Soeharto's New Order, most Balinese were, if asked, at pains to identify themselves as patriotic Indonesians first and Balinese second. There were obvious reasons, mentioned above, for this. But their everyday speech and actions made it clear that at other levels they saw themselves as Balinese first and Indonesian in specific respects only. So although they obediently flew flags on Independence Day, recited the principles of Pancasila readily, and deferred to government advice and direction in matters ranging from agriculture to religious practice, they were also, in private conversations, between the lines of everyday speech and in media such as wayang kulit (shadow puppet) performances and cartoons, critical of the government of the day if not the state itself (Warren, 1993).

This ambivalence became increasingly evident at the height of tourism growth in the 1990s, as frustration over a perceived gap between the economic benefits accruing to (especially central) government from tourism and those accruing to Bali. This occurred directly through taxation and indirectly through the ownership of tourism facilities. The two main taxes involved were a land tax (pendapatan asli daerah or PAD) and a special tax on the takings of hotels and restaurants (pajak hotel dan restoran or PHR), the latter is by far the larger source of tax

21 I am referring here to widespread Western perceptions post $9 / 11$ of a monolithic and threatenting 'Islamic world' dominated by sentiments of the kind articulated by Osama bin Laden. This perception was fed by the Western media and was most pronounced in countries such as the UK and Australia that are most closely aligned with the USA's 'war on terror'. 
revenue in South Bali. Revenue from both taxes increased enormously with tourism growth as hotel and restaurant takings increased and as land values rose. Revenue generated by PHR is distributed more to local than to central levels of government (MacRae, 1997) but there was a widespread perception among the Balinese that their tourism industry was being used as a cash cow by governments and that they were bearing the costs with little recompense.

The large development projects referred to above were initiated and carried out by Jakarta-based capital but were made possible only by the active cooperation of all levels of government. In the early 1990s, a series of the projects received unusually quick permits from the relevant departments at all levels of government and, where necessary, local communities were induced or coerced to give up land for the projects to proceed. This sparked unprecedented protests at all levels of Balinese society and reflected a growing loss of confidence in the commitment of government to Balinese interests (Suasta and Connor, 1999).

This confidence ebbed further as the legitimacy of Soeharto's New Order slipped away and, in the economic and political chaos after his regime's demise in 1998, there were calls all over Indonesia for decentralisation or regional autonomy. In Aceh and West Papua these calls have been for total independence. Balinese have stopped short of this but many believe that they need much greater control over various aspects of the destiny of their island. The autonomy that has been granted has been to the local (kabupaten) levels than that of Bali as a whole (provincial level). The thrust of Ajeg Bali, however, emphasised the unity of Bali as much as its differentiation from the rest of Indonesia.

\section{Foreign Influences}

Balinese culture has, since the Dutch took over in the early twentieth century, been inseparable from its representations in various Western media, which in turn are closely linked to tourism, as cause and as effect. The Balinese people have taken readily to the economic benefits of this relationship but their attitude to the cultural effects has been 
more ambivalent.

Many aspects of Balinese culture, from the arts to consumption habits, have embraced elements of Western origin enthusiastically but selectively. Nonetheless, they have retained a wariness about Western cultural, especially moral, influences. When issues arise, such as abuse of alcohol or new drugs, prostitution or paedophilia, there is a tendency to label them 'non-Balinese,' 'foreign' or even 'Western'. This line of thinking has been evident in local reactions to the recent well-publicised cases of Australians arrested, charged and convicted for drug offences in Bali (MacRae, 2006).

This perception is to some extent not just Balinese, but reflects a more general ambivalence throughout Indonesia about foreign or Western cultural influence. For instance, the recent escalation of the use of various drugs at many levels of Indonesian society has given rise to widespread public concern. Because it is a relatively new phenomenon in most people's experience, it is seen as having come from elsewhere and when foreigners are caught importing, dealing or using drugs, it is interpreted as evidence that such practices are foreign (MacRae, 2006; see also Avonius, 2009). ${ }^{22}$

In May 2005, Tempo, a national news magazine, published a special report on the activities of foreign paedophiles in Bali. Although the report stopped short of describing it as a Western cultural practice, it did say that paedophilia was a problem 'brought by tourism' (see also Lanus, 2001). Likewise, Tempo gleefully seized the opportunity, presented by the delivery of envelopes of mysterious white powder to the Indonesian Embassy in Canberra, in the wider context of Australian public and media reaction to an Australian tourist, Schapelle Corby, being found guilty of importing drugs to Bali. Hitting the terrorism ball back into Australia's court, Tempo, on the cover of its edition of 12 June 2005, printed the headline 'Aksi teror di Australia: Jamaah Corbyah'

22 This interpretation is not withstanding the large numbers of Indonesians also convicted of drug offences and ignores the wider social and economic context in which drug abuse occurs. 
['Terror action in Australia: Jamaah Corbyah']. ${ }^{23}$

Balinese generally see Western tourists as essentially non-threatening economic assets, even as friends with a common interest in a particular vision of Bali. They also see Western culture as having much to offer but harbour deep fears about aspects of foreign cultural influence, as something they need to protect themselves against. In this respect they see themselves as sharing a generically Asian or Eastern culture with the rest of Indonesia, even if in other ways they prefer to distance themselves from Indonesia. ${ }^{24}$

\section{Understanding Indonesia? Or Imagining Indonesia?}

What can we understand about Indonesia from these particular Balinese understandings of Indonesia? First, and most obviously, what we call Indonesia is clearly not a political and cultural monolith, but is complex, multi-faceted and in a constant process of change, so we can not realistically expect to understand it in any formulaic way. Indeed any simplistic metaphors or models, such as 'the world's largest Muslim nation' are likely to perpetuate potentially dangerous misunderstandings. Second, understanding Indonesia depends on the position of the viewer: from within or without; from the point of view of the government, the military or the people; from an Islamic, Hindu or Christian perspective; from Jakarta or Bali or Aceh or West Papua. Third, if we take Bali as an example, it is clear that Indonesians themselves understand Indonesia in complex and sometimes contradictory ways: Balinese people see themselves as Indonesians but also as Balinese; they are proud of this nation, which their grandfathers fought and died for, but they have mixed feelings about its central government and some of its people.

When Benedict Anderson (1983) coined his famous description of nationalisms as 'imagined communities', it was based largely on his experience of Indonesia. Since then it has been argued that whole regions

23 For a range of discussions of the Corby case, see Noszlopy (2006).

24 For a local analysis of the ambivalence and contradictions in Balinese responses to drugs and prostitution, see Lanus (2001). 
such as 'Southeast Asia' or the 'Asia-Pacific' are also the product of imaginings, often supported by specific political and economic agendas (Acharya, 1999; Nonini, 1993). The struggle of my own country, New Zealand, to imagine and re-imagine itself as a nation-clean, green and nuclear free; liberal in ideology but neo-liberal in practice; part monocultural and part multicultural behind an official veneer of 'biculturalism'; European by descent, language and culture but located in the Pacific; 'part of Asia' according to its politicians, but in many segments of society profoundly and wilfully ignorant about Asiareminds us that this imagining of community and identity is ongoing in perhaps every nation and is not without its contradictions.

I suggest that any attempt to understand Indonesia will necessarily be partial (in both senses of the word). Understandings from the outside will be through the various lenses we unavoidably use to simplify complex realities. And what gets lost in top-down, national-level understandings of another country are the millions of ordinary people whose understandings of their own nation are as confused as those of outsiders. In the case of Indonesia, they are perhaps the reality we understand least but have most need to.

\section{After Ajeg Bali: Bali, Indonesia and the World}

The discussion above is a snapshot taken at a critical moment when the Balinese experienced their relationship with the Indonesian nation in a particular and intensified way, and from which we can learn something. Since then, much has changed. Internationally, images of political instability and terrorism in Indonesia have been replaced by those of tsunamis, earthquakes and mudflows. The extraordinary growth booms in China and India have been much celebrated but Indonesia too has been quietly rebuilding economically. Politically, it has rebuilt quietly too, with the political instability of the post-Soeharto years giving way to the relatively stable and moderate Yudhoyono presidency.

In Bali, tourism has bounced back to unprecedented levels, employment and prosperity are increasing again and the concerns about immigration 
and Islam expressed above have receded. ${ }^{25}$ Ajeg Bali has virtually disappeared from public discourse. The reasons for this are not entirely clear, but the most obvious one is simply that the crisis that Ajeg Bali was responding to has passed and the issues it sought to address are no longer critical.

Nationally, Reformasi of the political and administrative systems has proceeded steadily, especially in terms of regional autonomy. Elections of local leaders (especially for bupati, the heads of districts, and for gubernur, the heads of provinces) occur regularly throughout the country (Erb and Sulistiyanto, 2009). In Bali these have been the focus of considerable public interest but have largely been orderly. This has not resulted in a widespread sense of control over their own lives but Balinese people do at least know that the politicians controlling their lives are themselves Balinese, with some understanding of Balinese concerns. Electoral politics in Bali have turned not on specific policies, let alone national issues, but largely on perceptions of the sensibilities and sensitivities of candidates to generically Balinese concerns (MacRae and Darma Putra, 2007; 2008; 2009). In the 2008 elections for governor however, two of the three candidates emphasised familiar themes: protection of traditional culture and security and one candidate was disadvantaged by accusations of being too open to Islam. The winning candidate, Made Mangku Pastika, was in fact the police chief responsible for catching the Bali bombers and one of the heroes of the Ajeg Bali movement. In this way, although the Ajeg Bali discourse has faded away, some of its main ideas have been incorporated in the formal political process.

As a result of all this, understanding Indonesia has not suddenly become easier, but the absence of dramatic events means at least that the stereotypical views, which dominated the first half of the decade, are less of an obstacle. This opens a space for us to refocus on the real issues in need of understanding. Nationally, the residual issue most

25 Ironically, this paper will be published at a time close to the date referred to in the inflammatory document mentioned above but its predictions have turned out to be somewhat overstated. 
widely seen as undermining the gains of reformasi, desentralisasi and demokratisasi, is the persistence of corruption. Once the exclusive privilege of the elite, it is now referred to as having been 'democratised' and 'decentralised' to all levels of government and business. ${ }^{26}$

In Bali, corruption is also an issue but, in the context of a new era of tourism, prosperity and development, it is but one factor exacerbating a range of more visible side-effects of the boom. The most obvious of these consequences is environmental. Already motor vehicle traffic, pollution, water and waste are significant problems and all the indications are that they will increase, threatening the island's reputation as a tourist destination. The most vocal group concerned about these problems comprises foreigners living in Bali, but the environmental matters are also being discussed more in the local media as well as concerning ordinary Balinese (Bali Blog, 2007; Bali Times, 2007; Bali Post, 2008a,b; 2009; Carroll, 2004; Gies, 2009).

The return of capital-intensive development projects, drawn once again by the new boom, is an additional cause of these problems. But these development sites are also the sites where local environmental issues intersect with Jakarta capital and national corruption problems (Bali Post, 2008a). Although the problems are local, the pattern and the capital are national; but the devolution of decision-making and the accompanying corruption to more local levels, makes it harder for Balinese to blame outsiders for the problems. In an economic sense, Bali has already been largely 're-Ajeg-ed' but in another sense the problems Ajeg Bali sought to address have been so internalised into Balinese political and administrative processes, that there is no longer any outside threat to give meaning to a discourse of Ajeg.

If we return to a national viewpoint, variations on this set of problems are evident all over the country; the infamous Lapindo mudflow scandal the most spectacular and best-known case. From an international perspective, the economic growth of India and, especially, China are

26 This generalisation is based on many conversations with ordinary Indonesians, as well as an endless stream of high-profile cases and discussion in local, national and international media (for example, Bloomberg, 2010). 
widely seen as models to be emulated by other developing countries (Huang and Khanna, 2003). Much less widely discussed are the massive environmental consequences associated with this growth, let alone the price to be paid by the less privileged citizens of these countries. Similarly with Indonesia; Bali may usefully be seen, like Jakarta, as a laboratory for exploring the costs and benefits of unsustainable development and the options for sustainable development. It is the urgent task and responsibility of the social sciences, and especially in Indonesia, to study such developments, within and beyond the archipelago, as lenses through which to understand the options for the future of Indonesia. Those outside Indonesia would do well to remember that the issues confronting Indonesia are, in rather concentrated form, the issues we will all face sooner or later.

\section{References}

Acharya, A. (1999). 'Imagined proximities: the making and unmaking of Southeast Asia as a region'. Asian Journal of Social Science 27(1): 55-76.

Allen, P and C Palermo. (2005). 'Ajeg Bali: multiple meanings, diverse agendas'. Indonesia and the Malay World 33(97).

Anderson, B. (1983). Imagined communities: reflections on the origin and spread of nationalism. London: Verso.

Avonius, L. (2009). 'Indonesian adat communities: promises and challenges of democracy and globalisation'. In The politics of the periphery in Indonesia: social and geographical perspectives, (eds) M Sakai, G Banks, JH Walker. Singapore: NUS Press.

Bali Blog. (2007). 'Environmental issues in Bali', 16 January 2007. http://www. baliblog.com/travel-tips/environmental-issues-in-bali.html

Bali Post. (2004). Ajeg Bali: sebuah cita-cita. Denpasar: Bali Post.

- (2005). 'Stop investor luar kuasai tanah Bali', Bali Post, 9 February 2005.

. (2005). 'Gubernur daftar jadi anggota Koperasi Krama Bali', Bali Post, 17 May 2005.

(2005). 'Koperasi Krama Bali benteng ekonomi rakyat', Bali Post, 18 May 2005.

(2005). 'Wesnawa daftar jadi anggota Koperasi Krama Bali: saatnya jadi tuan di daerah sendiri', Bali Post, 20 May 2005.

. (2005). 'Widiada-Sumawidana jadi anggota: Koperasi Krama Bali dapat 'support' luar biasa', Bali Post, 21 May 2005. 
. (2005). 'Koperasi Krama Bali dideklarasikan: menikmati bakso dan soto ala Krama Bali', Bali Post, 27 May 2005.

(2005). 'Harapan kepada Koperasis Krama Bali: jadi kekeatan ekonomi Bali yang terkoordinasi’, Bali Post, 28 May 2005.

-------. (2005). 'Krama Bali jangan jadi ‘Benalu’, Bali Post, 22 June 2005.

-. (2005). '50 siswa segera masuk pesraman Ajeg Bali', Bali Post, 24 June 2005.

(2008a). 'Diskusi lingkungan 'Bali Post': amdal pesanan, percepat kehancuran Bali’, Bali Post, 6 June 2008.

-------. (2008b). 'Bencana Lingkungan Ancam Denpasar', Bali Post, 2 August 2008. . (2009). 'Isu lingkungan terpinggirkan', Bali Post, 5 April 2009.

Bali Times. (2007). 'Bali's environment problems mounting: activist', Bali Times, 20 April 2007. http://www.thebalitimes.com/2007/04/20/bali\%E2\%80\%99senvironmental-problems-mounting-activist/

Barth, F. (1993). Balinese worlds. Chicago, London: University of Chicago Press.

Bloomberg, JG. (2010). 'Indonesia's image as corrupt worsens', Jakarta Globe, 8 March 2010. http://www.thejakartaglobe.com/analysis/indonesias-image-ascorrupt-worsens/362667

Carroll, M. (2004). 'Environmental problems cloud recovery of Bali's tourism industry', The Washington Post, 11 April 2004.

Chauvel, R. (2009). 'Papuan nationalism: Christianity and ethnicity'. In (eds) M Sakai, G Banks, JH Walker, The politics of the periphery in Indonesia: social and geographical perspectives. Singapore: NUS Press.

Couteau, J. (2002). 'Bali: crise en paradis'. Archipel 64: 231-254.

Darma Putra, N. (2004a). 'Bali pasca-bom: konflik, kekerasan, dan rekonstruksi identitas budaya seputar "Ajeg Bali"”. In (eds) W Cika, GNK Putrayasa, W Teguh and GAAM Triadnyani, Garitan budaya Nusantara dalam perspektif kebinekaan. Denapasar: Larasan.

-------. (2004b). Bali menuju jagaditha: aneka perpektif. Denpasar: Pustaka Bali Post.

Denpasar Post. (2005). 'Bergabung dengan KKB: PGRI ingin wujudkan SDM berkualitas'. Denpasar Post, 24 June 2005.

(2005). 'Akte pendirian Koperasi Krama Bali diserahkan'. Denpasar Post, 9 July 2005.

Dwipayana, AAGNA. (2003). 'Metamorfosis Ajeg Bali'. Sarad Bali 43 (November 2003): 40-41.

-------. (2005). Globalism: pergulatan politik representasi atas Bali. Denpasar: Uluangkep.

Erb, M and P Sulistiyanto (eds). (2009). Deepening democracy in Indonesia: direct elections for local leaders (pilkada). Singapore: Institute of Southeast Asia Studies. 
Gies, E. (2009). 'As tourism rises in Bali, what to do with waste?'. New York Times, 24 May 2009.

Hefner, R. (1985). Hindu Javanese: tengger tradition and Islam. Princeton: Princeton University Press.

Huang, Y and T Khanna. (2003). 'Can India overtake China?', Foreign Policy, JulyAugust 2003.

Kerepun M.K. (2004). 'Kelemahan karakter orang Bali derdasarkan analisis SWOT'. In (eds) W Ardika and N Darma Putra. Politik kebudayaan dan identitas etnik. Denpasar: Balimangsi and Fakultas Sastra, Universitas Udayana.

Lanus, S. (2001). 'The triangle of denial, indifference and silent hope: drug abuse and prostitution in Bali'. In (eds) U Ramseyer and GR Panji Tisna. Bali: Living in Two Worlds: a Critical Self-portrait. Basel: Schwabe.

MacRae, G. (1992). 'Tourism and Balinese culture'. MPhil Thesis, University of Auckland.

. (1997). 'Economy, ritual and history in a Balinese tourist town'. PhD thesis, University of Auckland.

-------. (2004). 'Art and peace in the safest place in the world: a Balinese culture of apoliticism'. In (ed.) T Reuter. Inequality, crisis and social change: the muted worlds of Bali. London, New York: Routledge Curzon.

-------. (2005). 'Growing rice after the bomb: where is Balinese agriculture going?' Critical Asian Studies 37(2): 209-232.

------. (2006). 'Fear and loathing in our own holiday paradise: the strange tale of Schapelle Corby (et al.)'. Australian Journal of Anthropology, 17(1): 79-85.

MacRae, G. and Darma Putra, N. (2007). 'A new theatre-state in Bali? Aristocracies, the media and cultural revival in the 2005 local elections'. Asian Studies Review 31: $171-89$.

MacRae, G. 2008) “"A peaceful festival of democracy”: aristocratic rivalry and the media in a local election in Bali'. Review of Indonesian and Malaysian Affairs 42(2): 107-46.

-------. (2009). 'Not just an elite game' Inside Indonesia 97.

Nonini, D. (1993). 'On the outs on the rim: an ethnographic grounding of the "AsiaPacific imaginary"'. In (ed.) A Dirlik. What is in a rim?: critical perspectives on the Pacific Region idea. Boulder: Westview.

Noszlopy, L. (ed.). (2006). 'The Schapelle Corby show: drugs, media and society'. Australian Journal of Anthropology 17(1): 70-85.

Picard, M. (2005). 'From Kebalian to Ajeg Bali: tourism and Balinese identity in the aftermath of the Bali bombings'. In (eds) M Hitchcock, V King and M Parnwell. Tourism in Southeast Asia: new perspectives. Copenhagen, Honolulu; NIAS, University of Hawaii Press.

Ramseyer, U and IGN Panji Tisna. (2001). Bali, living in two worlds: a critical selfportrait. Basel: Schwabe. 
Ramstedt, M (ed.). (2004). Hinduism in modern Indonesia. a minority religion between local, national, and global interests. 1-34. London, New York: Routledge Curzon.

Rini, AS. (2004a). 'Menghayati hakikat hidup Hindu dalam orientasi keajegan Hindu'. Bali Post, 2004.

(2004b). 'Perlu "Grand Design" pembangunan manusia Hindu'. Bali Post. 2004.

Santikarma, D. (2001). 'The power of "Balinese culture"'. In (eds) U Ramseyer and GR Panji Tisna. Bali: Living in two worlds: a critical self-portrait. Basel: Schwabe.

Schulte Nordholt, H. (2007). Bali, an open fortress, 1995-2005: regional autonomy, electoral democracy and entrenched identities. Singapore: NUS Press.

Seriana, N. (2005). 'Tingkatkan rasa memiliki Bali'. Bali Post, 21 June 2005.

Suasta, Pand LConnor.(1999). 'Democratic mobilization and political authoritarianism: tourism developments in Bali'. In (eds) R Rubinstein and L Connor. Staying local in the global village: Bali in the twentieth century. Honolulu: University of Hawaii Press.

Sukiada, N. (2004). ‘Apa yang dimaksud dengan Ajeg Bali?’ In (eds) W Cika, GNK Putrayasa, W Teguh and GAAM Triadnyani, Garitan budaya Nusantara dalam perspektif kebinekaan. Denapasar: Larasan.

Vickers, A. (1987). 'Hinduism and Islam in Indonesia: Bali and the pasisir world'. Indonesia, 44: 31-58.

(1989). Bali: a paradise created. Ringwood: Penguin.

Warren, C. (1993). Adat and dinas: Balinese communities in the Indonesian State, Kuala Lumpur, New York: Oxford University Press. 